\title{
Molecular characterization of new Buffelgrass (Cenchrus cilliaris) genotypes
}

\author{
Abdulrahman Al-Soqeer, Soleman M. Al-Otayk, Mohamed I. Motawei* \\ Department of Plant Production \& Protection, College of Agriculture \& Veterinary Medicine, Qassim University, \\ Buraydah 51452, P.O. Box 6622, Saudi Arabia
}

*Corresponding author: rumotawei@hotmail.com

\begin{abstract}
Buffelgrass (Cenchrus ciliaris L. Link) is an African agamospermous grass that has been widely introduced into arid regions of the world to improve rangelands for cattle production and as a result, it has invaded adjacent habitats. Cenchrus ciliaris is apomictic, a condition that is normally associated with low genetic variation within populations, but even moderate levels of genetic variation among populations could account for differences in invasiveness. We used Inter-Simple Sequence Repeat markers (ISSRs) to examine genetic variation among buffelgrass genotypes collected from nine different locations in the central region of Saudi Arabia, and three introduced cultivars. The genetic similarity coefficients among the twelve buffelgrass genotypes ranged from 0.66 to 0.94. Maximum similarity was observed between local populations. Introduced cultivars 'Biloela', 'Gayndah' and 'USA' were quite distinct from local populations. The dendogram constructed with UPGMA analysis revealed three clusters. In general, the study revealed the presence of considerable genetic diversity that could be used for further analysis for specific traits of interest.
\end{abstract}

Keywords: buffelgrass (Cenchrus ciliaris); genetic diversity; ISSR markers.

Abbreviations: ISSR, Inter-Simple Sequence Repeat markers; UPGMA, unweighted pair group method with arithmetic average; $\mathrm{CTAB}$, cetyltrimethylammonium bromide; PCR, Polymerase chain reaction.

\section{Introduction}

Cenchrus is a member of 780 genera of Poaceae and is native to Asia, Africa, Australia, and America (Govaerts, 2011). Among Cenchrus species, Buffelgrass C. ciliaris is common in dry, sandy areas such as Saudi Arabia (Al-Soqeer et al., 2016). Buffelgrass has been introduced into many tropical and subtropical areas of the world for grazing purposes. Buffelgrass is widely distributed and is resilient to a number of harsh environmental conditions. It can withstand strong winds, low annual rainfall, acute erosion, and a nutrient-depleted soil profile (Ziegler et al. 2000). Buffelgrass is an important pasture grass in many parts of the tropics, mainly because of its low cost of establishment, high yields and high level of nutrients, tolerance to drought conditions and crop pests, and its ability to withstand heavy grazing and trampling by livestock (Duke 1983). Some strains are also good for forage during the wet season in the tropics. It is often touted for its ability to increase the flow of milk in cattle and give a sleek and glossy appearance to their coats (Duke 1983).

Genetically, buffelgrass is primarily reproduced through aposporous apomixis with some sexual genotype (KharratSouissi et al., 2014). When sexual reproduction occurs, it is predominately cross-pollinated. Three ploidy levels are known to exist in buffelgrass: Tetraploid $(2 n=4 n=36$, the most common one), pentaploid $(2 n=5 n=45)$, and hexaploidy $(2 n=6 n=56)$ (Jessup et al., 2003). Buffelgrass has several advantages as a model for genetic mapping studies of polyploidy, perennial forage grasses. It is protogynous, which allows hybridizations to be made without hand emasculations of florets. Obligate apomictic buffelgrass genotypes can be maintained long-term as seeds instead of vegetative plants. The high levels of heterozygosity in buffelgrass result in adequate levels of DNA polymorphism for genetic mapping in hybrids between most genotypes. Genetic mapping of hybrid buffelgrass populations was first accomplished by Jessup et al. (2003). They placed molecular markers across a majority of the buffelgrass genome, distinguished between genomic regions with disomic and tetrasomic inheritance, and included markers capable of screening genotypes for apomictic reproduction. Considerable genetic diversity was reported in buffelgrass germplasm maintained in germplasm collected provenances of Tunisia and Saudi Arabia using molecular markers (AFLP and SSR) (Kharrat-Souissi et al., 2011; AlSoqeer et al., 2016).

For introduction of buffelgrass into agricultural system, and to be an economically profitable forage crop under the Central region of Saudi Arabian environmental conditions, it is necessary to assess the possibility of its adaptation and cultivation, and to determine its nutrition value. The objective of this research was to compare the genetic structure of buffelgrass genotypes collected from nine different locations in the central region of Saudi Arabia, and three introduced cultivars.

\section{Results and Discussion}

\section{Genetic diversity of buffelgrass genotypes}

In ISSR analysis, a total of 58 bands were observed, with 5.3 bands per primer (Table 2). Eighteen out of 58 bands (31\%) 
Table 1. Accession name along with collection site names.

\begin{tabular}{lcc}
\hline Ser \# & Genotype name & Site name \\
\hline 1 & Gayndah & Introduced \\
2 & Biloela & Introduced \\
3 & USA & Introduced \\
4 & UIO & Uionaljaua \\
5 & BUR-1 & Buraidah-1 \\
6 & BUR-2 & Buraidah-2 \\
7 & ALG & Algat \\
8 & ZIL & Zilfi \\
9 & ALM & Almajmaah \\
10 & UIA & Uiaynah \\
11 & RIY-2 & Riyadh-2 \\
12 & RIY-3 & Riyadh-3 \\
\hline
\end{tabular}

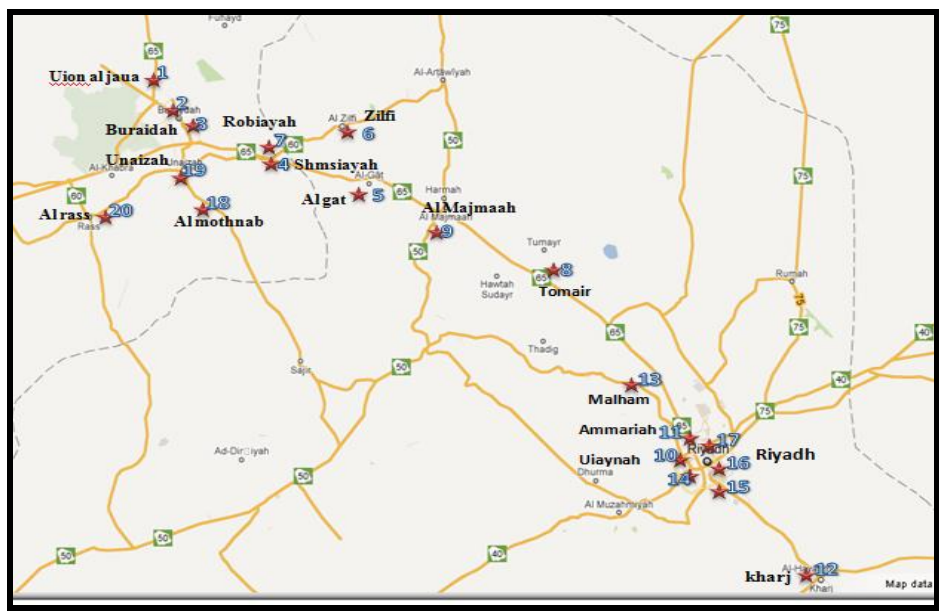

Fig 1. Locations of the collected buffelgrass accessions from central region of Saudi Arabia, numbers refer to population.

Table 2. ISSR primers used in this study and a summary of the ISSR markers from buffelgrass genotypes.

\begin{tabular}{lccc}
\hline Primer & $\begin{array}{c}\text { Primer } \\
\text { sequence }\end{array}$ & $\begin{array}{c}\text { Amplified } \\
\text { products }\end{array}$ & $\begin{array}{c}\text { Fraction polymorphic } \\
\text { fragments }^{\mathrm{a}}\end{array}$ \\
\hline P02 & $(\text { ATCG })_{4}$ & 0 & $0 / 0$ \\
D12 & $(\mathrm{GA})_{6} \mathrm{CG}$ & 5 & $1 / 5$ \\
D14 & $(\mathrm{CAC})_{3} \mathrm{GC}$ & 5 & $0 / 5$ \\
D24 & $(\mathrm{CA})_{6} \mathrm{CG}$ & 6 & $3 / 6$ \\
$\mathrm{HB13}$ & $(\mathrm{GAG})_{3} \mathrm{GC}$ & 7 & $1 / 7$ \\
$\mathrm{HB14}$ & $(\mathrm{CTC})_{3} \mathrm{GC}$ & 11 & $1 / 11$ \\
UBC807 & $(\mathrm{AG})_{8} \mathrm{~T}$ & 5 & $2 / 5$ \\
UBC810 & $(\mathrm{GA})_{8} \mathrm{~T}$ & 6 & $3 / 6$ \\
UBC811 & $(\mathrm{GA})_{8} \mathrm{C}$ & 5 & $2 / 5$ \\
UBC823 & $(\mathrm{AC})_{8} \mathrm{C}$ & 3 & $2 / 3$ \\
UBC825 & $(\mathrm{AC})_{8} \mathrm{~T}$ & 5 & $3 / 5$ \\
\hline
\end{tabular}

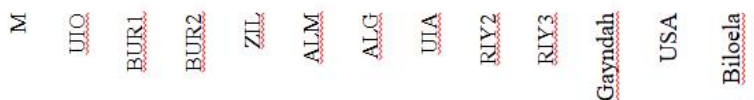

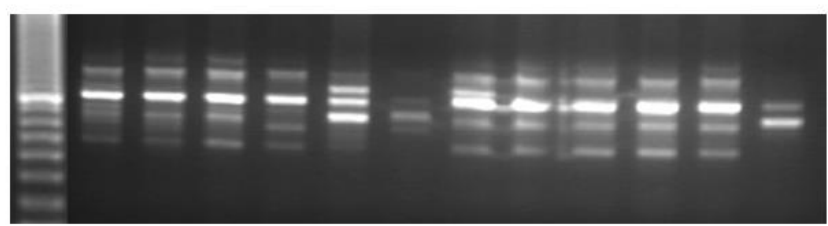

Fig 2. Polymorphism revealed using primer ISSR primer to amplify genomic DNA purified from the tested buffelgrass genotypes. 


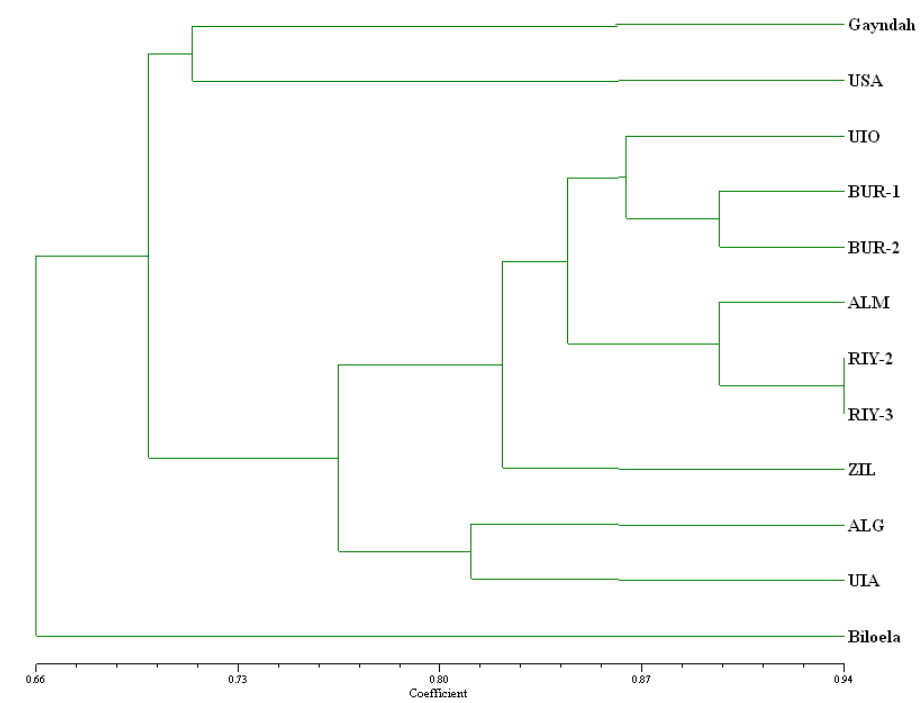

Fig 3. Dendrogram constructed from similarity coefficients and showing the clustering of the tested buffelgrass genotypes.

were polymorphic. The number of amplification bands per primer varied between 0 and 11 . The trinucleotide repeats (CTC) primer had the highest bands. On the contrary, tetranucleotide repeats did not amplify with DNA of buffelgrass genotypes. This might indicate that tri- and dinucleotide-based ISSR markers could provide potential marker in buffelgrass genome.

In this study, the pair-wise genetic distance estimates of the twelve buffelgrass populations were analyzed. The genetic similarity coefficients among all buffelgrass ranged from 0.66 to 0.94 . Maximum similarity was observed between local populations (Fig. 2). Introduced cultivars ' Biloela', 'Gayndah' and 'USA' were quite distinct from local populations (Fig. 2). Cluster analysis was conducted to generate a dendogram elucidating for relationships among buffelgrass populations. The dendogram constructed with UPGMA analysis revealed three clusters (Fig. 3). Cluster I contained introduced cultivars Gayndah and USA. Cluster II contained all local populations and divided into two sub-clusters that included the following: (i) genotypes Uionaljaua, Buraidah-1, Buraidah-2, Almajmaah, Riyadh-2, Riyadh-3 and Zilfi, and (ii) genotypes Algat and Uiaynah. Custer III contained the introduced cultivar Biloela. Comparison to the other genotypes, the last genotype Biloela gave the highest values of water use efficiency (Al-Soqeer et al., 2016). Buffelgrass has a moderate salt tolerance, however, cultivar Biloela has shown higher salt tolerance than other cultivars (Griffa et al., 2010). Moreover, it is interesting to note that genotypes Buraidah-1 and Buraidah-2, which were found in the same sub-cluster using ISSR primers, had the lowest drought susceptibility index (DSI < 1) and labeled as drought-tolerant genotype (Al-Soqeer et al., 2016). The observed clustering using ISSR markers showed the presence of a wide range of genetic diversity in the collection of the bufelgrass genotypes. The results from this study is in line with previous reports (Jorge et al., 2008; SávGutiéc et al., 2017; Al-Soqeer et al., 2016), which documented the genetic diversity of the collection based on agro-morphological variables. However, Jorge et al. (2008) reported the lack of clear clustering of the collection, based on agromorphological variables, which may be due to the limited polymorphism of agro-morphological variables compared to molecular markers (Nybom et al., 2014).
Several factors may affect levels of genotypic diversity among populations of buffelgrass (Gutierrez-Ozuna et al., 2009). Founder events during colonization and the frequency of sexual reproduction (Hignight et al., 1991) may affect levels of variation within populations while patterns of migration may affect levels of differentiation. The presence of wide genetic diversity using molecular markers was also reported in buffelgrass germplasm (Negawo et al., 2020). Gutierrez-Ozuna et al. (2009) estimated the genetic diversity among Buffelgrass (C. ciliaris) populations. They found that 27 reproducible bands generated with three primers, in which 16 (59.26\%) were polymorphic. In addition, KharratSouissi et al. (2011) concluded that AFLP markers revealed the existence of genotypic variations between individuals of the same sib-ship of buffelgrass populations. Their results underline the possibility of sexual reproduction, recombination, and gene flow within and between populations of $C$. ciliaris.

\section{Materials and Methods}

\section{Buffelgrass germplasm collection/exploration}

Twelve buffelgrass seed fascicles were collected from a population located in Central Region of Saudi Arabia (Table 1). For the collection of germplasm, 9 sites were selected within central region (Fig. 1). Nine accessions were collected from the community at the peak of the seed dispersal season, (one accession for each site). In addition, three buffelgrass varieties, Gayndah, USA, and Biloela were introduced. Collected seeds were stored at laboratory condition in paper bags for different time durations until initiation of the experiments.

\section{DNA extraction}

Bulk leaf samples from 10 plants of each of the twelve buffelgrass populations were collected. The bulk sample of leaves was first ground into fine powder with liquid nitrogen. Genomic DNA was extracted adding $260 \mu \mathrm{L}$ of CTAB extraction buffer and $975 \mu \mathrm{L}$ of TE buffer. The mixture was then agitated and subsequently centrifuged at $12,000 \mathrm{rpm}$ for $8 \mathrm{~min}$. The supernatant was eliminated and the 
precipitated was resuspended in $250 \mu \mathrm{L}$ of CTAB buffer and $750 \mu \mathrm{L}$ of TE buffer. Samples were centrifuged at $12,000 \mathrm{rpm}$ for $8 \mathrm{~min}$, the supernatant was eliminated and the precipitated was resuspended in $600 \mu \mathrm{L}$ of $2 \times$ CTAB buffer. The samples were treated with ribonuclease $7000 \mathrm{u} / \mathrm{mL}$ ( $4 \mu \mathrm{L}$ per sample) at $37^{\circ} \mathrm{C}$ for $20 \mathrm{~min}$ to digest RNA. After this treatment, $25 \mu \mathrm{L}$ of proteinase- $\mathrm{K}(20 \mathrm{mg} / \mathrm{mL})$ was added and incubated at $65^{\circ} \mathrm{C}$ for $30 \mathrm{~min}$. The samples were placed on ice for $15 \mathrm{~min}$. DNA was isolated using chloroform: octanol 24:1 (adding $600 \mu \mathrm{L}$ per sample and homogenizing), centrifuged at $9000 \mathrm{rpm}$ for $12 \mathrm{~min}$, and the supernatant was transferred to a fresh centrifuge tube. DNA was precipitated with $600 \mu \mathrm{L}$ of cold isopropanol $\left(-20^{\circ} \mathrm{C}\right)$ and maintained for $12 \mathrm{~h}$ at $-20^{\circ} \mathrm{C}$. After that time, samples were centrifuged at $12,500 \mathrm{rpm}$ for $7 \mathrm{~min}$ and the supernatant was eliminated. The pellet was washed agitating gently for 5 min with $70 \%$ ethanol $\left(-20^{\circ} \mathrm{C}\right)$. The pellet was dried, resuspended in $100 \mu \mathrm{L}$ of PCR grade water, and stored at $4{ }^{\circ} \mathrm{C}$. DNA concentration of each extract was quantified using an Eppendorf biophotometer.

\section{ISSR assay}

The ISSR-PCR method was carried out according to Negaoka and Ogihara, (1997). Amplification was carried out in $25 \mu \mathrm{l}$ reaction volumes, containing $1 \mathrm{X}$ Taq polymerase buffer ( 50 $\mathrm{mM} \mathrm{KCl}, 10 \mathrm{mM}$ Tris, $\mathrm{pH} 7.5,1.5 \mathrm{mM} \mathrm{Mg} \mathrm{Cl}$ ) and 1 unit of Taq polymerase (Pharmacia Biotech, Germany) supplemented with $0.01 \%$ gelatin, $0.2 \mathrm{mM}$ of each dNTPs (Pharmacia Biotech, Germany), 50 pmol of ISSR primers (Table 2), and 50 ng of total genomic DNA. Amplification was performed in a thermal cycler (Thermolyne Amplitron).

\section{Data analysis}

ISSR data were scored for presence (1), absence (0) or as a missing observation (9), and each band was regarded as a locus. Two matrices, one for each marker, were generated. The genetic similarities (GS) were calculated according to Nei and $\mathrm{Li}$ (1979): GS = 2Nij/( $\mathrm{Ni}+\mathrm{Nj})$, where $\mathrm{Nij}$ is the number of bands present in both genotypes $\mathrm{i}$ and $\mathrm{j}, \mathrm{Ni}$ is the number of bands present in genotypes $\mathrm{i}$, and $\mathrm{Nj}$ is the number of bands present in genotype $\mathrm{j}$. Based on the similarity matrix, a dendrogram showing the genetic relationships between genotypes was constructed using the unweighted pair group method with arithmetic average (UPGMA) though the software NTSYS-pc version 2.11 (Rohlf, 2000).

\section{Conclusion}

A collection of buffelgrass (a high-value forage grass) was assessed in this study using molecular markers. Genetic diversity analysis using ISSR markers revealed the presence of a substantial amount of genetic diversity in the collection of buffelgrass. In general, the generated information could be used to select genotypes with diverse genetic makeup for further evaluation in multi-location trials.

\section{Acknowledgements}

We would like to thank the King Abdul Aziz City for Science and Technology (KACST) for financially supporting this research work under the Project "Studies on adaptation and cultivation of Buffelgrass (Cenchrus ciliaris L.), and its natural habitat, genetic properties and nutritional value" Project No. 09-BIO 744-09.

\section{References}

Al-Soqeer A, Motawei MI,, Menshawy AM (2016) Selection of buffelgrass (Pennisetum ciliare L. Link) genotypes for drought stress based on field performance and molecular markers. J Food Agric Environ. 14: 162-168.

Duke JA (1983) Cenchrus ciliaris L. Handbook of Energy Crops, unpublished

(http://www.hort/purdue.edu/newcrop/duke_energy/Cenchrus_ ciliaris.html).

Govaerts RHA (2011) World checklist of selected plant families published update. Facilitated by the Trustees of the Royal Botanic Gardens, Kew.

Griffa, S, Ribotta A, Colomba EL, Tommasino E, Carloni E, Luna C, Grunberg K (2010) Evaluation seedling biomass and its components as selection criteria for improving salt tolerance in Buffelgrass genotypes. Grass Forage Sci. 65: 58-361.

Gutierrez-Ozuna R, Eguiarte LE, Molina-Freaner F (2009) Genotypic diversity among pasture and roadside populations of the invasive buffelgrass (Pennisetum ciliareL. Link) in north-western Mexico. J Arid Environ. 73: 26-32.

Hignight KW, Bashaw EC, Hussey MA (1991) Cytological and morphological diversity of native apomictic buffelgrass, Pennisetum ciliare (L.) Link. Botanical Gazette. 152: 214-218.

Jessup RW, Burson BL, Burow G, Wang YW, Chang C, Li Z, Paterson $A H$, Hussey MA (2003) Segmental allotetraploidy and allelic interactions in buffelgrass (Pennisetum ciliare (L.) Link syn. Cenchrus ciliaris L.) as revealed by genome mapping. Genome. 46: 304-313.

Jorge MAB, Van De Wouw M, HansonJ, Mohammed J (2008) Characterisation of a collection of buffelgrass (Cenchrus ciliaris). Trop Grassl. 42: 27-39.

Kharrat-Souissi A, Baumel A, Torre F, Juin M, Siljak-Yakovlev S, Roig A, Chaieb M (2011) New insights into the polyploid complex Cenchrus ciliaris L. (Poaceae) show its capacity for gene flow and recombination processes despite its apomictic nature. Aust J Bot. 59(6): 543-553.

Kharrat-Souissi A, Siljak-Yakovlev S, Brown SC, Baumel A, Torre F, Chaieb M (2014) The polyploid nature of Cenchrus ciliaris L. (Poaceae) has been overlooked: New insights for the conservation and invasion biology of this species-A review. Rangel J. 36: 1123.

Nagaoka, T, Ogihara, Y (1997) Applicability of inter-simple sequence repeat polymorphisms in wheat for use as DNA markers in comparison to RFLP and RAPD markers. Theor Appl Genet. 94: 597-602.

Nei M, Li W (1979) Mathematical model for studying genetic variation in terms of restriction endonucleases. Proc Natl Acad USA. 76, 5269-5273.

Negawo AT, Assefa Y, Hanson J, Abdena A, Muktar MS, Habte E, Sartie AM, Jones CS (2020) Genotyping-by-sequencing reveals population structure and genetic diversity of a Buffelgrass (Cenchrus ciliaris L.) collection. Diversity 12: 88; doi:10.3390/d12030088.

Nybom H, Weising K, Rotter B (2014) DNA fingerprinting in botany: Past, present, future. Investig Genet. 5: 1.

Rohlf, FJ (2000) NTSYS-PC numerical taxonomy and multivariate system, Version 2.1 Applied Biostatistics Inc., New York.

SávGutiéc R.A, Morales Nieto CR, Hanson J, Santellano Estrada E, Jurado Guerra P, Villanueva Avalos JF, Melgoza Castillo A (2017) Caracterización forrajera de ecotipos de zacate buffel en condiciones de temporal en Debre Zeit, Etiopía. Rev Mex Cienc Agrícolas. 8: 13-26.

Ziegler AD, Warren SD, Perry JL, Giambelluca TW (2000) Reassessment of revegetation strategies for Kaho'olawe Island, Hawai'i. Journal of Range Management. 53: 106-113. 